\title{
A Research on the Baroque Sensibility of Richard Crashaw's Poetry
}

\author{
Yi Zheng ${ }^{182}$ \\ ${ }^{1}$ College of International Studies, Southwest University, Chongqing, China; \\ ${ }^{2}$ School of Linguistics and Literature, University of Electronic Science and Technology of China, Chengdu, China \\ Correspondence: Yi Zheng, School of Linguistics and Literature, University of Electronic Science and \\ Technology of China, No. 2006, Xiyuan Ave, West Hi-Tech Zone, 611731, Chengdu, Sichuan, China. Tel: \\ 86-136-8848-3836. E-mail: zhengyismile@aliyun.com
}

Received: September 18, 2014 Accepted: October 13, 2014 Online Published: November 25, 2014

doi:10.5539/ells.v4n4p50 URL: http://dx.doi.org/10.5539/ells.v4n4p50

This paper is supported by "the Fundamental Research Funds for the Central Universities of UESTC (University of Electronic Science and Technology of China) (NO. ZYGX2012J136)".

\begin{abstract}
Richard Crashaw is a religious poet of the 17th century English literature. His poems are full of strong religious emotions. In demonstrating his emotions, Crashaw follows his heart's calling instead of following the restrictions of Classicism. Such religious emotions are deeply influenced by the Baroque culture of the 17th century. Deeply related with the religious movement, Baroque culture is both reserved and open, which contributes to the religious emotions of Crashaw's poems and his unique Baroque poems.
\end{abstract}

Keywords: Richard Crashaw, Baroque sensibility

\section{Introduction}

Richard Crashaw is a religious poet of the 17th century England. Living in the age of Baroque period, his poetry is imbued with strong Braque style and religious emotions. T. S. Eliot thinks that Crashaw "as the representative of the baroque spirit in literature" (Eliot, 1929, p. 125). Douglas Bush also points out that "Crashaw is the one conspicuous English incarnation of the "baroque sensibility" (Bush, 1962, p. 147). Besides Baroque elements, there are strong religious emotions in his poetry. The emotions showed in his poems can be classified into four types: the meditative emotion, the redemptive emotion, the ecstatic emotion and the devotional emotion.

\section{The Meditative Emotion}

Strong religious emotions are the main component of the Baroque culture, for Baroque starts from the Counter-Reformation movement. The most typical embodiment of religious feelings of the age is the day-long and day-night meditative practice. Mental prayer is a long tradition of Christionality. As Jordan Aumann states: "fervent Christians had to resort to a spirituality that was one of withdrawal from the world, fortified by well-regulated spiritual exercises and definite methods of prayer. This itself was not an innovation in the Christian life, for Christ had taught the necessity of self-discipline, a certain detachment from the world and the practice of prayer (Aumann, 1985, p. 157)". Mediation on the life of Christ played a significant role in the devotional life of the Baroque age, as those books Meditations on the Life of Christ, Lorenzo Scupoli's The Spiritual Combat, Louis de Blois' Institutio spiritualis and St. Ignatius Loyola's Spiritual Exercises wrote. For example, "Everything in the world," says the Spiritual Combat, "can be related to the events of Christ's life and death; everything about you will be a reminder of them". St. Ignatius designs a four-step month-long spiritual exercise for devote individuals. Even the ordinary layman of the time was constantly encouraged to work toward a state of mind in which "Christ crucified appears unto him in everie place, and at all times (Martz, 1962, pp.71-73)". Living in such an age when prayer and meditation became the fashion for pious disciples, Crashaw followed the suit. During his study at Pembroke College, Cambridge, he joined into a religious group called "Little Gidding Community". Founders of this community, Nicholas Ferrar and his family established a system of daily offices for its members to observe: they either read the Bible, or drone hymns during the day; at night, they practiced nightly vigils. As an intimate of the family, Crashaw "rejoiced in their way of life, and frequently rode over from Cambridge to pass his days in the ordered sequences of the offices and to share in the night 
watches" (Warren, 1957). Besides, he remained single lifelong. It is no exaggeration to state that he almost spent his whole life in silent contemplation and prayer. As both a Baroque poet and religious poet, undoubtedly, Crashaw in his thought prayed for God and his son, Jesus Christ, as those poems "Hymn in the Holy Nativity", "Hymn for New Year's Day", "Hymn in the Glorious Epiphanie" demonstrate. The emotions expressed in these poems are deep and internal. In Crashaw's mediation, Jesus Christ becomes the sun, which chases away the night and brings new life to the world.

Take "Hymn in the Holy Nativity" as an example. Based on the Luke 2:15-20, the "Hymn" is, in effect, a song of joy sung by the shepherds Tityrus and Thyrsis to celebrate the divine birth of Jesus. They glorify the coming of Christ into the secular world, for he is the supernatural sun, who has superseded the natural sun and gives true light, warmth and hope to men, as the following stanza show:

Tityrus. Gloomy night embrac't the Place

Where The Noble Infant lay.

The BABE look't up and shew'd his Face;

In spite of Darkness, it was DAY.

It was THY day, SWEET! And did rise

Not from the EAST, but from thine EYES. (Crashaw, 1970, p.79)

Before the birth of Christ, the whole human world is a hell-like place where darkness lingers and men suffer eternal original sin without any hope. However, his coming emanates light and drives away the "Gloomy night". Crashaw here describes "a new kind of dawn: Christ is his own East. The second shepherd, Thyrsis, goes on to praise that the eyes are not only the dawn, but also the spring" (Williams, 1963, pp.52-53).

Chorus It was THY day, Sweet

Thyrs. WINTER chidde aloud; and sent

The angry North to wage his warres.

The North forgot his fierce Intent;

And left perfumes in stead of scares.

By those sweet eyes' persuasive powrs

Where he mean't frost, he scatter'd flowrs

Chorus By those sweet eyes'

Both. We saw thee in thy baulmy Nest,

Young dawn of our eternal DAY!

We saw thine eyes break from their EASTE

And chase the trembling shades away.

We saw thee; and we blest the sight

We saw thee by thine own sweet light. (Crashaw, 1970, pp. 79-81)

Here, the newly-born infant Christ becomes the "dawn of our eternal DAY". Marc F. Bertonasco comments that "the comparison of the natural light and warmth of the earthly sun with the divine light and warmth radiating from the Son of God is a favorite one of Crashaw's. The Divine Son is the source of love and intellectual activity, and the cause of spiritual life, just as the earthly sun is the source of physical warmth and light and the cause of natural life (Bertonasco, 1971, p. 12)". In the two stanzas, those images such as "perfume", "flowrs", "Nest", "Day" make a contrast of the difference before and after the coming of Jesus and convey a sense of new life and hope, especially the word "day". This word refers to extraordinary illumination or a state of grace, whereby the Christian is united to Christ in faith, hope, and love (Bertonasco, 1971, p. 12). Besides, the poet does not mention the color of the flowers, but it must be gorgeous. The smell of the flowers is usually associated with the imagery of the eastern counties (Williams, 1963, p. 53), for many of those eastern countries have the tradition of making perfume with flowers. So, "flowers" implies that Christ is also the god of the East.

The celebration of Christ into the world in the poet's meditation reaches its climax in the $13^{\text {th }}$ stanza of the poem, where "Heaven in earth, and God in MAN" (Crashaw, 1970, p. 83). Here, the paradox of Incarnation shows. Paradox is one of the favorable means of Baroque poems, where either oxymoron or antithesis is often used 
(Segel, 1974, p. 106). The paradoxical description of "Eternity \& span", "sommer \& winter", "Day \& Night", "Heaven \& earth", "God \& MAN" is combined together.

Full Chorus. Wellcome, all WONDERS in one sight!

Eternity shutt in a span.

Sommer in Winter. Day in Night.

Heaven in earth, and GOD in MAN.

Great little one! whose all-embracing birth

Lifts earth to heaven, stoops heav'n to earth. (Crashaw, 1970, p. 83)

\section{The Devotional Emotion}

As religion is a main component in Baroque culture, besides contemplation mentioned above, fervent Christians follow other forms of "ascetics", including fasting, austerities and continence. For example, St. Ignatius Loyola, St. Teresa and Crashaw are famous martyrs at that time. Carrying out exercises of the monastic tradition is to guarantee internal piety through external disciplines. As a pious religious poet, Crashaw shows strong devotional emotions in his poetry, as "The Hymn to St. Teresa" writes. This poem recounts and glorifies St. Teresa's life: she runs away from home to obtain martyrdom as a symbol of her desire to "dy in love's delicious fire" which is to mark the rest of her life (Crashaw, 1970, p. 52). In retelling the saint's story, the poet illustrates how effective that sacred love in transforming the human personality, i.e., to make her conduct life-sacrificial heroism. To be specific, as A.D. Cousins says, this poem demonstrates three stages of her: the first one of her as infant heroine in search of spiritual union through physical martyrdom, the second one of her finding in adulthood intimations of spiritual union through spiritual martyrdom, and a last of her entering heaven and receiving eternal beatitude (Cousins, 1991, p.162).

The poem starts with the infant Teresa's desire for union with Christ through self-sacrifice. Long before she understands the temporal life, she seeks a death to unite with Christ:

Scarse has she learn't to lisp the name

Of Martyr; yet she thinks it shame

Life should so long play with that breath

Which spent can buy so brave a death.

She never undertook to know

What death with love should have to doe;

Nor has she e're yet understood

Why to show love, she should shed blood

Yet though she cannot tell you why,

She can LOVE, and she can DY. (Crashaw, 1970, p.54)

Readers may wonder why the little six-year old girl has such great courage. The opening line declares: "Love, thou art Absolute sole lord / OF LIFE and DEATH (Crashaw, 1970, p.54)". It is the love for Christ encourages her supreme heroic deeds. Thus, she dares to go to the Moor and at the cost of her life, converts them to Christianity:

She'l to the Moores; and trade with them,

For this unvalued Diadem.

She'l offer them her dearest Breath,

With CHRIST'S Name in't, in change for death.

She'l bargain with them; and will give

Them GOD; and teach them how to live

In him: or, if they this deny,

For him she'l teach them how to DY.

So shall she leave amongst them sown 
Her LORD'S Blood; or at lest her own. (Crashaw, 1970, p. 55)

Here, this part recounts what Teresa says in her Vida: "I used to discuss with this brother of mine how we could become martyrs. We agreed to go off to the country of the Moors, beginning our bread for the love of God, so that they might behead us there; and even at so tender an age, I believe the Lord had given us sufficient courage for this, if we could have found a way to do it...(Teresa, 2004, pp. 2-3)" .

However, Christ is merciful. He is not willing to accept such an early martyrdom, so there are these lines:

SWEET, not so fast! Lo thy fair Spouse

Whom thou seekst with so swift vowes,

Calls thee back, and bidds thee come

T'embrace a milder MARTYDOM. (Crashaw, 1970, p. 55)

The poet, sympathetic with and respectful for Teresa's heroic deeds, reminds her that there maybe another way of devotion. Therefore, with sublime heroic resolve, this love-impelled child seeks another form of self-devotion, i.e., something of spiritual union in her adulthood: "THOU art love's victime; and must dy / A death more mysticall and high. (Crashaw, 1970, p. 56)" Following these lines, the poet represents the mythical transverberation of the saint in "The Flaming Heart", where she becomes the mistress of Christ and experiences the ecstasy of spiritual marriage with him.

After spiritual union with Christ, Teresa finally enters into heaven where she is warmly welcomed by angles and all of her suffering changes into beauty:

All thy old woes shall now smile on thee

And thy paines sitt bright upon thee

All thy sorrows here shall shine,

All thy SUFFERINGS be divine.

TEARES shall take comfort, and turn gems

And WRONGS repent to Diademms. (Crashaw, 1970, p. 57)

At the end of the poem, the poet highly praised the triumphant image of Teresa and her exemplary nature of life: "Which who in death would live to see, / Must learn in life to dy like thee (Crashaw, 1970, p. 58)." The weak body who contains a spirit that longs so ardently to be united with the Beloved must be glorified and followed by others.

\section{The Redemptive Emotion}

"Redemption" is an important motif of Christianity (Michael, 2005, p.4), for being saved by God is the forever wish of human beings. And we all know that God is merciful. In order to bring people back to their paradise, the Garden of Eden, he asks his son Jesus to come to the human world. Stripped and crucified, Jesus finally sacrifices himself to fulfill the mission.

In Crashaw's poetry, "Song upon the Bleeding Crucifix", employing the technique of "Emblem", expresses the poet's gratitude to Jesus' self-sacrificial behavior. Emblem, a combination of a motto, picture, and poem, puts before the reader's eyes words and image focused on a conceit. It functions as evoking meditation and drawing the contemplative mind from sensuous perception to spiritual insight (Cousins, 1991, pp. 22-23). In the reign of Elizabeth, emblem books were first introduced into England from the Continent and quickly became popular (Freeman, 1948, p.1). So emblem poems are often accompanied with pictures to turn the poem into visual images, such as Hermann Hugo' s "Anima in the labyrinth". This poem uses the picture of a labyrinth where a pilgrim totters to find the right way out of the human hell and up to the tower of paradise. There are some other poems whose words demonstrate vivid visual images between its lines, such as Edmund Spenser's The Faerie Queene. Crashaw often uses the latter to express his ideas.

For example, at the very beginning of the poem, there appears the image of Jesus' crucifixion:

Jesu, no more! It is full tide.

From thy head and from thy feet,

From thy hands and from thy side

All the purple Rivers meet. (Crashaw, 1970, p. 111) 
The second line "from head to feet" forms a vertical line, while the third line "from hands to another side" shows a horizontal line, which combines with the vertical line forming a cross where Jesus suffers and thus bleeds. Bertonasco says that in the Crucifixion, the wounds and blood of Christ are usually symbols of love, beautiful and precious not only because they are Christ's, but also because they heal mankind spiritually (Bertonasco, 1971, p. 12). Following this image and emotion, the poet describes the suffering Jesus' head, feet, hands and body in great detail to eulogize the greatness of his sacrifice:

What need thy fair head bear a part

In showres, as if thine eyes had none?

What need They help to drown thy heart,

That strives in torrents of it's own?

Thy restlesse feet now cannot goe

For us and our eternall good,

As they were ever wont. What though?

They swimme. Alas, in their own floud.

Thy hands to give, thou canst not lift;

Yet will thy hand still giving be.

It gives but $\mathrm{o}$, it self's the gift.

It gives though bound; though bound 'tis free.

But o thy side, thy deep-digg'd side!

That hath a double Nilus going.

Nor ever was the pharian tide

Half so fruitfull, half so flowing. (Crashaw, 1970, p. 72)

Here, Crashaw's redemptive emotion towards Christ is contained in these detailed descriptions where HE is stripped and spat. The tear in Jesus' eyes might be the tears of his numerous followers, undoubtedly including Crashaw. His feelings start from the silent tears to the last stanza's shouting-out explosion, reaching its climax where he compares the "deep-digg'd side" of Jesus' body to "a double Nilus going". St. Francis de Sales thinks that meditation often on the Crucifixion can become increasingly aware of God's overwhelming love for men and to feel pity for the Divine Victim, thus growing in divine love (Bertonasco, 1971, p. 8). Such description makes readers sense as if they are witnessing this particular moment. Bennett thinks that this expression is typical of Crashaw's method: he dwells on the actual wounds and their texture and seeks to communicate the horror and pity of the particular moment (Bennett, 1971, pp. 98-99).

\section{The Ecstatic Emotion}

The religious strife of the 16th and 17th century, especially the Counter-Reformation is the main event that stands behind the emergence of the Baroque culture. The Counter-Reformation is a reform carried out within the Roman Catholic Church to deal with the prosperous Reformation in the European Continent. A lot of Orders join in the movement, among which Jesuits is the most influential. St. Ignatius Loyola, leader of the organization, who often claims that he sees the vision of God, holds that visual culture is important to glorify God. So the Jesuits, especially the Roman Catholic Church encourage luxuriant and grand style. This conception was evident across the whole span of visual culture, from painting and sculpture to architecture (Snodin \& Llewellyn, 2009, p.76), especially the churches. Such design gives people a sense of sensuousness and openness of expression. As for the Baroque poet Crashaw, he combines an extraordinary amount of emotional intensity with an extraordinary purity of spirit, i.e., the combination of sensation and spirit. Reflected in his poetry, he often compares it to sexual love to demonstrate he longs for the heaven to achieve a spiritual union with Christ, such as the poem "The Flaming Heart" shows.

This poem is based on a mystical experience of St. Teresa. Crashaw "admired her intellectual qualities as well as her spiritual worth" (Klemans, 1971, p. 153). In her account, she experienced the ecstasy of transverberation: "I would see beside me, on my left hand, an angle in bodily form - a type of vision which I am not in the habit of seeing, except very rarely....In his hands I saw a long golden spear and at the end of the iron tip I seemed to see a point of fire. With this he seemed to piece my heart several times so that it penetrated to my entrails. When he drew it out, I thought he was drawing them out with it and he left me completely afire with a great love for God 
(Teresa, 2004, p. 244).” Using Teresa's experience, Crashaw illustrates the love between God and man.

At the very beginning of this poem, the poet asks readers to transpose the saint and the seraph for the flame of this loving human heart is higher than the flame of the fieriest seraph and thus attracts him to descend from the heaven to see: "This is the mistresse flame; and duteous he / Her happy fire-works, here, comes down to see (Crashaw, 1970, p. 63)". The word "mistresse" gives readers a sensory impression: the saint looks like the bride in the Song of Solomon, who desires for the union of her bridegroom. After the seraph stabs the saint, the poet reminds readers once again to reverse the scene: "Redeem this injury of thy art; / Give HIM the vail, give her the dart (Crashaw, 1970, p. 63)", for "Give then the dart to her who gives the flame; / Give him the veil, who kindly takes the shame (Crashaw, 1970, p. 64)". In other words, after being stabbed by the angle, the sacred fire of divine love kindles her. The flame changes her from the ignited to the igniter, the "incendiary", who sets both the angle and the poet aflame with divine love:

His be the bravery of all those Bright things,

The glowing cheeks, the glistering wings;

The Rosy hand, the radiant DART;

$\cdots$

O sweet incendiary! shew here thy art,

Upon this carcasse of a hard, cold, hart,

Let all thy scatter'd shafts of light, that play

Among the leaves of thy larg Books of day,

Combin'd against this BREST at once break in

And take away from me my self and sin,

This gratious Robbery shall thy bounty be;

And my best fortunes such fair spoils of me. (Crashaw, 1970, p. 64)

The divine love here not only lightens the hard, cold heart of the speaker, but also takes away his sin, which makes him feel it is his fortune to enjoy such privilege. As for the saint, the dart stricken by the seraph wounds her: "The wounded is the wounding heart (Crashaw, 1970, p. 64)". Undoubtedly she feels painful, but what she feels more is the joy of uniting with God both spiritually and physically. The joy is so strong that even the pain becomes sweet and makes her wish to continue the suffering, to pray God to continue to wound her yet more deeply, as she says in her autobiography, the Vida: "The pain was so sharp that it made me utter several moans; and so excessive was the sweetness caused me by this intense pain that one can never wish to lose it, nor will one's soul be content with anything less than God (Teresa, 2004, p. 244)." Austin Warren comments on this pain and joy commingling moment: "God pieces the soul with such darts of fire that pain and joy are simultaneous and of equal strength: joy, because God loves the soul and longs for it and visits it; pain, because the soul cannot love God as he deserves, because God's visitations are temporary, because the body cannot endure the strain put upon it by rapture, because the soul longs for death and perfect union with its Spouse (Warren, 1957, p. 144)". So the dart is the symbol of their union, while her wound is the symbol of her love. Witnessing the triumphant progress of Teresa towards heaven, the poet becomes passionate. Thus, in the last 16 lines of the poem, there is the moving and memorable invocation to the saint about the poet's wish of enjoying the same pain-felt ecstasy of union with God:

O thou undanted daughter of desires!

By all thy dowr of LIGHTS and FIRES;

By all the eagle in thee, all the dove;

By all thy lives and deaths of love;

By thy larg drauhts of intellectuall day,

And by thy thirsts of love more large then they'

By all thy brim-fill'd Bowles of fierce desire

By thy last Morning's draught of liquid fire;

By the full kingdome of that finall kisse 
That seiz'd thy parting Soul, and seal'd thee his;

By all the heav'ns thou hast in him

(Fair sister of the SERAPHIM!)

By all of HIM we have in THEE; (Crashaw, 1970, p. 65)

Here, the repetition of the word "By" and the piling up of roughly the same sentence patterns build up the rapture in the poet's mood, and leads effectively to the conclusion: "Leave nothing of my SELF in me (Crashaw, 1970, $p$. 65)". A short couplet which follows the statement further illustrates it: "Let me so read thy life, that I Unto all life of mine may dy (Crashaw, 1970, p. 65)". The poet ends up pleading his own case before the saint, hoping that she may ravish him. Thus, like Teresa, the poet, if not reaching the state of ardent excitement which inflames him with divine madness, at least comes very close to it. Mario Praz comments that in the whole course of $17^{\text {th }}$-century literature there is no higher expression of that spiritualization of sense as demonstrated in this poem (Praz, 1958, p. 262).

\section{Conclusion}

As a famous Baroque poet of the $17^{\text {th }}$ century, Crashaw puts the popular Baroque culture into his poetry and thus generates these different emotions. Different these emotions might be, they all show how pious the poet is towards God. Crashaw's world is a world of love, a world, in Warren's words, "of man's inner life at its mystical intensity, the world of devotion expressing itself through the sacraments and ceremonial and liturgy; it is a world which knows vision and rapture, tears and fire... (Warren, 1957, p. 206)."

\section{References}

Aumann, J. (1985). Christian spirituality in the Catholic tradition. California: Ignatius Press.

Bennett, J. M. A. (1971). Five metaphysical poets. London: Cambridge University Press.

Bush, D. (1962). English literature in the earlier seventeenth century, 1600-1660 (2nd ed.). Oxford: Oxford University Press.

Cousins, A. D. (1991). The Catholic religious poets from Southwell to Crashaw. London: Sheed \& Ward.

Crashaw, R. (1970). The complete poetry of Richard Crashaw (George Walton Williams, Ed.). New York: Doubleday \& Company, Inc.

Eliot, T. S. (1929). For Lancelot Andrewes. London: Faber \& Gwyer Limited.

Freeman, R. (1948). English emblem books. London: Chatto \& Windus.

Klemans, P. A. (1971). Richard Crashaw: England's Baroque Poet (Unpublished doctoral dissertation). University of Pittsburgh, the United States.

Martz, L. L. (1962). The poetry of meditation. London: Yale University Press.

Praz, M. (1958). The flaming heart. New York: Doubleday Anchor Books.

Segel, H. B. (1974). The Baroque poem. New York: E.P. Dutton \& Co., Inc.

Snodin, M., \& Llewellyn, N. (2009). Baroque 1620-1800: Style in the age of magnificence. London: V \& A Publishing.

Teresa of Avila. (2004). The life of Teresa of Jesus (E. Allison Peers, Ed.). New York: Doubleday.

Walsh, M. (2005). Roman Catholicism: The basics. London: Routledge.

Warren, A. (1957). Richard Crashaw: A study in baroque sensibility. Michigan: The University of Michigan Press.

Williams, G. W. (1963). Image and symbol in the sacred poetry of Richard Crashaw. Columbia: University of South Carolina Press.

\section{Copyrights}

Copyright for this article is retained by the author(s), with first publication rights granted to the journal.

This is an open-access article distributed under the terms and conditions of the Creative Commons Attribution license (http://creativecommons.org/licenses/by/3.0/). 